\title{
Pengenalan Pupuk Organik Cair dan Sistem Biopori di Kampung Babakan, Tangerang
}

\section{(Introduction of Liquid Organic Fertilizer and Biopore System in Babakan Village, Tangerang)}

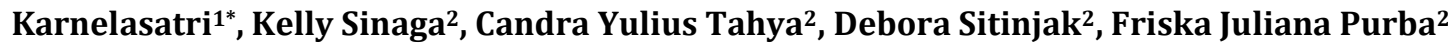 \\ 1 Program Studi DIII Farmasi, Fakultas Ilmu Kesehatan, Universitas Pelita Harapan, MH Thamrin Boulevard 1100, Kelapa \\ Dua, Kecamatan Kelapa Dua, Kota Tangerang, Banten 15811. \\ 2 Program Studi Pendidikan Kimia, Fakultas Ilmu Pendidikan, Universitas Pelita Harapan, MH Thamrin \\ Boulevard 1100, Kelapa Dua, Kecamatan Kelapa Dua, Kota Tangerang, Banten 15811. \\ *Penulis Korespondensi: nela.karnelasatri@gmail.com \\ Diterima Januari 2021/Disetujui September 2021
}

\begin{abstract}
ABSTRAK
Produksi sampah terus meningkat setiap tahunnya seiring dengan peningkatan jumlah penduduk di Indonesia. Sebagian besar dari sampah tersebut merupakan sampah organik yang memberikan dampak buruk pada lingkungan dan kesehatan manusia. Keadaan yang serupa di temui di Kampung Babakan, Binong, Kabupaten Tangerang. Kesadaran masyarakat tentang pengelolaan sampah masih perlu ditingkatkan karena sampah pada kampung ini belum dikelola dengan baik. Selain itu, frekuansi banjir tahunan di daerah ini cukup tinggi. Tim PkM Universitas Pelita Harapan melakukan penyuluhan dan pelatihan pembuatan pupuk organik cair dan sistem biopori untuk mengatasi masalah tersebut. Kegiatan ini bertujuan untuk menumbuhkan kesadaran serta memberikan pengetahuan kepada masyarakat Kampung Babakan, Binong tentang pengelolaan sampah dan kesehatan lingkungan. Metode yang digunakan adalah observasi lapangan serta pendidikan masyarakat, yaitu dengan penyuluhan dan pelatihan. Seluruh kegiatan berlangsung dengan baik dan warga memberikan respons positif dan aktif. Pelaksanaan PkM ini membuat warga Kampung Babakan memperoleh pilihan pengelolaan sampah yang baru untuk dapat mengelola sampah dengan lebih baik.
\end{abstract}

Kata kunci: pencemaran lingkungan, pupuk organik cair, sampah sisa makanan

\begin{abstract}
Every year waste production has increased because of human population growth in Indonesia. The most waste component is organic waste, which contributes a negative impact on the environment and human health. This situation is also discovered in the Babakan Sub-village, Binong, Tangerang District. The awareness of the society related to waste management is needed to improve due to the garbage in this village is not managed properly. Moreover, a high frequency of flooding has happened in this area during the rainy season. To deal with this problem, the community service team of Pelita Harapan University introduced a biopori system and organized a workshop to produce liquid organic fertilizer. The purpose of this activity was to raise awareness of waste management in the society of Babakan related to waste management and environmental health. The method used was the field observation and community education that was counseling and workshop. The service had been going great and the society of Babakan village, Tangerang, gave a positive and active response. These community services caused the society of Babakan, Binong, Tangerang to get new options to manage their waste more properly.
\end{abstract}

Keywords: environmental pollution, liquid organic fertilizer, organic waste

\section{PENDAHULUAN}

Peningkatan jumlah penduduk di Indonesia setiap tahunnya beriringan dengan peningkatan aktivitas manusia yang memproduksi sampah. Permasalahan sampah di Indonesia belum ditangani dengan baik, sehingga pada tahun 2016 dihasilkan sampah mencapai 65,2 juta ton (BPS
2018). Menurut Purwaningrum (2016), kegiatan pengurangan sampah hanya berkisar 5\%dan sisanya dibuang di TPA (Tempat Pemrosesan Akhir). Komposisi terbesar sampah yang ada di TPA ialah sampah organik, yaitu sebesar 70\%, sedangkan sebesar 14\% merupakan sampah plastik. Produksi sampah organik yang besar ini berpotensi menghasilkan gas metana $\left(\mathrm{CH}_{4}\right)($ Sari 
2018). Gas metana merupakan salah satu gas rumah kaca yang menyebabkan terjadinya pemanasan global berlebih ketika jumlah gas ini lebih banyak dari yang seharusnya. Pemanasan global yang berlebih akhirnya akan berdampak sangat luas salah satunya adalah perubahan iklim. Selain dampak lingkungan yang serius, permasalahan sampah ini juga berdampak pada kesehatan masyarakat (Miller \& Spoolman 2009).

Pemerintah Indonesia sendiri telah melakukan berbagai upaya untuk mengatasi permasalahan sampah sejalan dengan target Sustainable Development Goals (SDGs) poin ke 12.5, yaitu pada tahun 2030 setiap negara secara substansial mengurangi produksi limbah melalui pencegahan, pengurangan, daur ulang, dan penggunaan kembali, untuk dapat menjamin pola produksi dan konsumsi yang berkelanjutan (BPS 2016). Sejalan dengan upaya pemerintah tersebut, tim PkM Universitas Pelita Harapan berpartisipasi dalam pengembangan individu dan masyarakat dengan melaksanakan kegiatan pengabdian kepada masyarakat di Kampung Babakan, Binong, Kabupaten Tangerang. Pengelolaan sampah di kampung ini masih perlu ditingkatkan karena belum ada pengelolaan sampah terintegrasi baik yang dikelola oleh swasta maupun dikelola secara mandiri oleh masyarakat sekitar. Pengelolaan sampah dengan pengambilan sampah secara reguler yang kemudian dibuang ke TPA juga tidak dilakukan karena warga terbebani dengan biaya yang dikenakan untuk layanan tersebut. Selain itu, wilayah ini juga sering mengalami banjir disaat musim penghujan. Berdasarkan hal tersebut, tim PkM melaksanakan kegiatan penyuluhan sistem biopori dan pelatihan pembuatan pupuk organik cair sebagai solusi pengelolaan sampah organik di kampung ini.

Biopori adalah teknologi sederhana, tepat guna, dan ramah lingkungan yang murah serta mudah dikerjakan. Teknologi ini ditemukan oleh Kamir R. Brata dan merupakan salah satu solusi penanganan banjir. Biopori berupa pembuatan lubang silinder yang dibuat secara vertikal dengan diameter $10 \mathrm{~cm}$ dan kedalaman $100 \mathrm{~cm}$ (Brata \& Nelistya 2008). Ukuran kedalaman lubang dan diameter kemudian banyak dikembangkan. Selain berfungsi sebagai area resapan air, kedalaman lubang biopori juga dapat dimasukkan sampah organik agar dapat terurai dengan baik tanpa menimbulkan bau sehingga dampak negatif sampah organik bagi manusia dan lingkungan dapat diminimalisasi. Efektivitas laju resapan lubang biopori bergantung pada beberapa faktor seperti model lubang biopori yang dibuat. Jenis sampah organik yang dimasukkan memengaruhi laju pengomposan (Juliandari et al. 2013). Selain itu, efektivitas juga akan dipengaruhi oleh jenis tanah serta jumlah dan jenis dekomposer pada lubang tersebut. Pemanfaatan teknologi ini memberikan banyak keuntungan seperti perbaikan kualitas tanah karena aktivitas pengomposan sampah organik dalam lubang biopori, memperluas daerah resapan air, sehingga meminimalisasi resiko banjir, mengurangi emisi gas kaca yang dihasilkan dari pembusukan sampah organik, meminimalisasi resiko penyakit pada manusia yang disebabkan oleh bakteri dan jamur serta penyakit lainnya yang mungkin ditimbulkan oleh genangan air dan banjir. Penyuluhan tentang sistem biopori dengan luaran delapan lubang berdiameter $30 \mathrm{~cm}$ dan tinggi $80 \mathrm{~cm}$ telah dilakukan di Kelurahan Bojong Kulur, Gunung Putri, Kabupaten Bogor. Berdasarkan hasil evaluasi setelah tiga bulan sebuah lubang biopori cukup untuk memenuhi kebutuhan pembuangan sampah organik satu keluarga dengan jumlah anggota keluarga empat orang. Selain itu, sampah organik yang dibuang dalam lubang biopori sangat mudah terurai dan tidak menimbulkan bau (Zulaihah et al. 2018). Hasil tersebut menunjukkan bahwa pengelolaan sampah organik dengan cara ini memberikan hasil yang efektif.

Selain biopori, pembuatan pupuk organik cair (POC) merupakan alternatif lain dalam pengelolaan sampah yang diperkenalkan pada masyarakat Kampung Babakan, Binong, Kabupaten Tangerang. Pupuk organik cair adalah larutan dari hasil pembusukan bahan-bahan organik yang berasal dari sisa tanaman, kotoran hewan, dan manusia yang kandungan unsur haranya lebih dari satu unsur (Hadisuwito 2007). Walaupun pupuk organik umumnya memiliki kekurangan berupa jumlah unsur hara yang tidak konsisten karena bergantung pada bahan baku dan proses pembusukan (Sentana 2010), namun pada pupuk organik cair, kekurangan ini dapat diatasi dengan berbagai tindakan salah satunya adalah penambahan bakteri pengurai misalnya EM4 (Nur et al. 2016). Selain itu, efektivitas pupuk organik cair dalam pertanian dan perkebunan dilaporkan baik dan signifikan seperti pada budi daya pisang barangan (Zaini 2015), pertumbuhan dan hasil tanaman jagung manis (Puspadewi et al. 2016), pertumbuhan dan produksi sawi (Febriana et al. 2018), pertumbuhan dan hasil kentang (Marpaung et al. 2014) serta pertumbuhan dan hasil sayuran 
kubis (Marpaung 2017). Pembuatan pupuk organik cair dari sampah rumah tangga maupun kotoran hewan juga memiliki potensi yang sangat baik sebagai solusi pengurangan sampah organik yang terakumulasi di lingkungan maupun di TPA yang pada akhirnya berkontribusi besar pada produksi gas rumah kaca dan membahayakan kesehatan. Selain itu, pembuatan POC yang disertai dengan kegiatan pengelolaan sampah lainnya dan juga kegiatan bercocok tanam serta berternak dengan skala rumah tangga berhasil mendukung penataan lingkungan yang bersih dan sehat serta peningkatan kualitas hidup masyarakat seperti yang telah dilakukan pada kelompok PKK Perumahan Griya Satria, Bancarkembar, Kecamatan Puwokerto Utara (Widiyastuti \& Kartono 2019).

Melihat potensi yang dapat diperoleh dengan pemanfaatan dua teknologi tepat guna di atas, maka kegiatan PkM yang dilaksanakan bersama warga kampung Babakan, Binong ini bertujuan untuk meningkatkan kesadaran warga terhadap pengelolaan sampah serta kesehatan lingkungan dan mendorong warga untuk mengaplikasikan pengelolaan sampah mandiri dengan pembuatan pupuk organik cair (POC) dan sistem biopori. Selain itu, kegiatan ini juga menjadi wadah bagi dosen dan mahasiswa yang terlibat untuk membagikan pengetahuan, meningkatkan kemapuan berkomunikasi khususnya untuk para mahasiswa dan mengembangkan kemampuan berpikir kreatif seperti dalam penyusunan rancangan alat dalam pengembangan teknologi sederhana POC bagi masyarakat memanfaatkan peralatan bekas sehingga dapat menambah nilai guna dari barang tersebut.

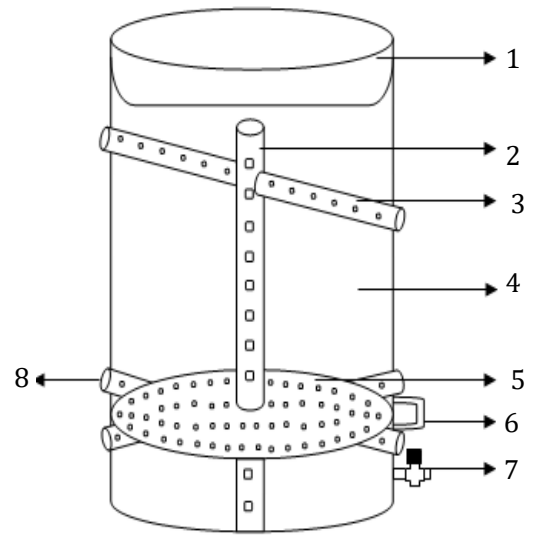

a

\section{METODE PELAKSANAAN KEGIATAN}

\section{Waktu, Tempat, dan Peserta Kegiatan}

Kegiatan PkM dilaksanakan di Kampung Babakan, Desa Binong, Kecamatan Curug, Kabupaten Tanggerang, Provinsi Banten pada bulan September-Oktober 2019. Mitra dari kegiatan ini adalah masyarakat Kampung Babakan.

\section{Alat dan Bahan}

Peralatan yang digunakan dalam penyuluhan adalah proyektor dan laptop, sedangkan dalam pelaksanaan workshop peralatan yang digunakan adalah dua set lengkap alat pemrosesan pupuk orgaik cair (POC) yang berasal dari sampah daur ulang, gambar peraga, dan dua set alat biopori. Bahan yang digunakan adalah pupuk cair dalam tahap proses tujuh hari sebagai contoh, bakteri EM4, pupuk cair hasil produksi, dan bibit tanaman untuk dibagikan pada warga. Alat pemrosesan POC yang dibuat dengan memanfaatkan barang-barang bekas seperti container bekas cat bangunan, pipa PVC bekas, dan lain sebagainya. Adapun gambar rancangan alat pemrosesan POC dan alat yang dibuat oleh tim ditunjukkan pada Gambar 1.

\section{Tahapan Pelaksanaan Kegiatan}

Kegiatan PkM ini dilakukan dalam tiga tahap pelaksanaan, yaitu tahap pertama adalah survei dan sosialisasi kegiatan, tahap kedua adalah pelaksanaan kegiatan, dan tahap ketiga adalah adalah evaluasi kegiatan. Tahap survei dilakukan pada Kamis, 22 September 2019. Pada tahap ini tim melakukan diskusi untuk waktu dan tempat

Gambar 1 a) Rancangan alat pemrosesan pupuk organik cair dan b) Alat pemrosesan POC dari container cat bekas dan hasil POC (dalam botol plastik). 
pelaksanan kegiatan PkM. Selain itu, tim juga mensosialisasikan tujuan pelaksanaan kegiatan, manfaat, serta target dari pelaksaan kegiatan pada perwakilan warga Kampung Babakan. Pada tahap ini tim juga mendiskusikan hal-hal yang perlu dipersiapkan agar kegiatan berlangsung dengan baik.

Tahap pelaksanaan penyuluhan serta workshop dilakukan pada tanggal 12 Oktober 2019. Tempat pelaksanaan kegiatan adalah di Mushola Nurus-Sa'Adah dengan luas sekitar 36 $\mathrm{m}^{2}$. Mushola ini dipilih karena merupakan tempat berkumpul warga Kampung Babakan. Peserta yang mengikuti kegiatan berjumlah 30 orang didominasi para ibu. Selain itu, kegiatan juga diikuti oleh lima orang kader desa di RT 5 yang antusias dan berperan aktif dalam pelaksanaan kegiatan. Selain warga RT 5, warga dan ketua RT lain juga mengikuti kegiatan tersebut.

Pada kegiatan penyuluhan disampaikan dua materi, yaitu materi tentang POC dan sistem biopori oleh tim dosen selama 40 menit. Pembuatan POC dilakukan dengan menyiapkan wadah pemrosesan terlebih dahulu. Alat pemrosesan dirancang dengan desain spesifik agar memudahkan dalam pengambilan hasil. Bahan dasar dan ukuran pembuatan alat pemrosesan POC beranekaragam sesuai dengan keperluan. Tim dosen menjelaskan pembuatan alat pemrosesan dari container bekas cat seukuran ember dengan diameter sekitar $30 \mathrm{~cm}$ dan tinggi $50 \mathrm{~cm}$. Hal ini ditujukan untuk mengoptimalkan pengelolaan sampah warga Kampung Babakan. Ukuran alat ini juga tepat untuk pembuatan POC skala rumah tangga dimana bahan POC-nya merupakan sisa sayur dan buah dari proses memasak sehari-hari. Warga cukup memasukan bahan pembuatan sesuai ukuran alat pemrosesan POC, menambahkan gula merah dan bakteri EM4 serta menutup alat pemrosesan selama 7-14 hari. Hasil POC dapat dimanfaatkan sebagai penyubur tanaman warga. Pada kegiatan penyuluhan, tim mendorong warga untuk aktif menanam sayur secara mandiri untuk konsumsi pribadi dan memanfaatkan sampah botol plastik bekas sebagai wadah karena jumlahnya cukup banyak ditemui di kampung ini akibat tidak dikelola dengan baik.

Materi kedua adalah tentang biopori, penyampaian materi diawali dengan penjelasan tentang informasi seputar bipori, alat biopori, cara membuat lubang biopori, dan manfaat biopori terutama untuk mengurangi potensi banjir yang relevan dengan permasalahan tahunan warga Kampung Babakan. Kegiatan kemudian dilanjutkan dengan diskusi dan tanya jawab dengan warga selama 20 menit. Setelah penyuluhan selesai, kegiatan kemudian dilanjutkan dengan workshop membuat alat pemrosesan POC dari barang bekas. Peralatan demo berupa alat pemrosesan setengah jadi dibawa untuk ditunjukkan kepada warga. Demo dan proses pembuatan dijelaskan oleh mahasiswa dan berlangsung selama 45 menit. Selanjutnya kegiatan dilanjutkan dengan pembuatan lubang biopori yang dicontohkan oleh dosen dan diikuti oleh warga selama 45 menit.

\section{Metode Evaluasi Kegiatan}

Pengumpulan data evaluasi dilakukan dengan membagikan kuesioner yang berisi 10 pertanyaan untuk melihat apakah warga memahami materi yang disampaikan. Selain itu, ada beberapa pertanyaan dalam kuesioner ditujukan untuk melihat tingkat keberhasilan dari kegiatan yang dilaksanakan. Selain kuesioner, mahasiswa juga melakukan wawancara langsung pada perwakilan warga dan kader desa. Data kuesioner yang diperoleh diolah dengan menggunakan excel dan wawancara langsung pada warga didokumentasikan dalam bentuk video yang kemudian di upload di media youtube.

\section{HASIL DAN PEMBAHASAN}

Kegiatan PkM dilakukan dalam dua pendekatan yaitu, pelaksanaan observasi dan survei lapangan yang kemudian dilanjutkan dengan pendidikan masyarakat. Observasi dan survei lapangan dilakukan dengan wawancara pada ketua RT dan perwakilan warga. Berdasarkan hasil wawancara tersebut diperoleh tiga permasalahan utama di Kampung Babakan, yaitu 1) Warga Kampung Babakan tidak menggunakan jasa pengambilan sampah reguler karena keberatan dengan biaya yang harus dikeluarkan; 2) Sampah masih tidak dikelola dengan baik terlihat dari sampah plastik yang berserakan maupun sampah organik yang menimbulkan bau kurang sedap karena pengelolaan sampah hanya dilakukan dengan cara dibakar; dan 3) Seringkali terjadi banjir pada musim penghujan. Observasi dan survei lingkungan serta wawancara ditunjukan pada Gambar 2.

Berdasarkan permasalahan tersebut, tim melakukan pendidikan kepada masyarakat dengan pelaksanaan penyuluhan sistem biopori dan POC sebagai solusi pengelolaan sampah organik rumah tangga. Bentuk kegiatan yang dilakukan 


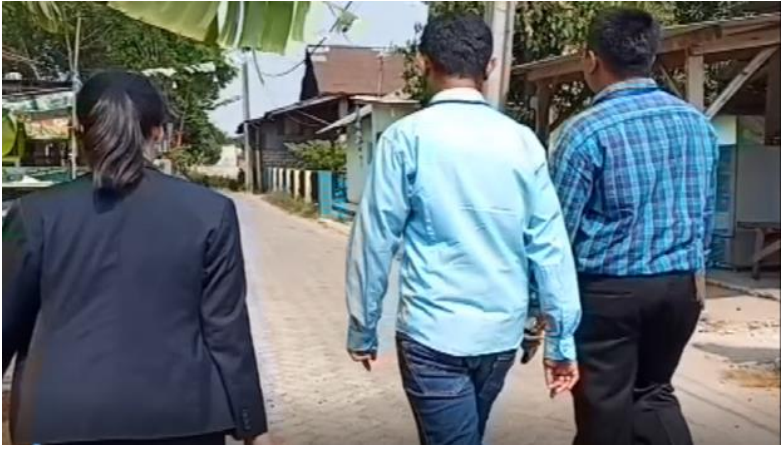

a

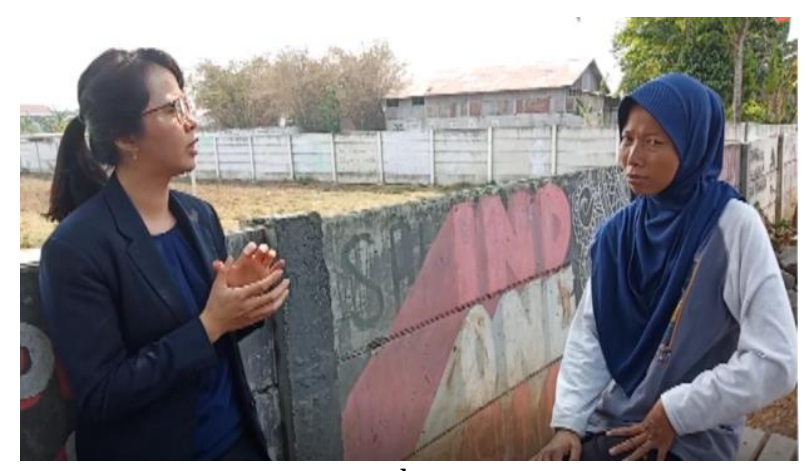

b

Gambar 2 a) Survei lapangan dan b) Wawancara dengan perwakilan warga Kampung Babakan.

berupa pemaparan materi tentang pentingnya pengurangan produksi sampah (reduce) dan pemilahan sampah agar sampah yang diproduksi warga dapat dikelola dengan mudah. Kegiatan kemudian dilanjutkan dengan pelatihan pembuatan POC dari pembuatan alat pemrosesan POC, cara pemrosesan, contoh POC berbahan kulit pisang yang sedang di proses, dan contoh produk POC.

Kegiatan penyuluhan dimuai dengan mempersiapkan kebutuhan penyuluhan seperti proyektor, alat pemrosesan pupuk cair sebagai alat peraga dan bahan untuk workshop, contoh produk POC, dan contoh sampah kulit pisang yang sedang diproses menjadi POC. Penyuluhan dibagi menjadi dua sesi, yaitu sesi pertama penyampaian materi tentang POC, jenis POC (aerob dan anaerob), langkah-langkah pembuatannya, sifat produk yang dihasilkan, faktor-faktor yang memengaruhi proses pengomposan, langkahlangkah pembuatan alat pemrosesan, bahanbahan dasar pembuatan POC, zat-zat yang terkandung dalam POC sesuai dengan sampah yang digunakan sebagai bahan dasarnya serta manfaat dan keuntungan yang mungkin akan didapatkan jika warga dapat mengimplementasikan teknologi ini dengan baik. Pada sesi kedua materi yang disampaikan adalah tentang lubang biopori, cara membuat, peralatan yang diperlukan serta keuntungan dari pembuatan lubang biopori. Kegiatan tersebut kemudian dilanjutkan dengan workshop pembuatan alat pemrosesan POC dengan mendaur ulang barangbarang bekas cat dan peralatan sederhana pendukung. Kegiatan ini dibantu oleh beberapa mahasiswa, sedangkan warga yang terlibat didominasi oleh para bapak serta para kader desa. Pembuatan alat pemrosesan biopori dari barang-barang bekas ini juga menjadi bagian tindakan reuse (penggunaan kembali) sampah padat, sehingga terintegrasi dengan tema pelaksanaan PkM, yaitu pengelolaan sampah.
Penyuluhan POC dan sistem biopori ditunjukan pada Gambar 3.

Tim menyiapkan dua contoh alat pemrosesan pupuk organik cair untuk ditunjukan pada warga agar bisa memahami dengan baik. Alat tersebut adalah kontainer metode aerob (sistem terbuka dan dengan bantuan udara yang keluar masuk kontainer selama proses pengomposan) dan metode anaerob (sistem tertutup dan tanpa udara yang keluar masuk kontainer selama pengomposan). Selain itu, contoh sampah organik dengan bahan dasar sampah kulit pisang yang sedang dalam proses (7 hari dari 14 hari) untuk menjadi pupuk organik cair juga dibawa, ditunjukkan, diajarkan prinsip-prinsip dasarnya serta disumbangkan pada warga sebagai contoh. Kegiatan demo ini ditunjukan pada Gambar 4.

Kegiatan dilanjutkan dengan pembuatan lubang biopori dipekarangan warga dengan alat yang telah disiapkan. Kegiatan ini dilakukan oleh dosen dan staf serta dibantu oleh ketua RT, para kader desa dan warga. Tim membawa dua model alat bor lubang biopori, yaitu alat bor dengan model ulir dan alat bor dengan model lubang tengah. Saat menggunakan alat bor model ulir tanah yang dibor dapat diangkat dan dipindahkan dengan mudah dengan hanya mengangkat alat. Sedangkan, saat menggunakan alat bor model lubang tengah tanah yang dibor tidak dapat diangkat dan dipindahkan langsung dengan praktis namun harus menggunakan alat tambahan lain seperti cangkul kecil atau linggis. Berdasarkan praktik tersebut, tim bersama dengan warga menyimpulkan bahwa model alat bor biopori yang lebih cocok dengan karakteristik tanah di daerah sekitar tempat tinggal warga adalah alat bor model ulir. Kegiatan pembuatan lubang biopori ini ditunjukan pada Gambar 5. Kegiatan diakhiri dengan ramah tamah dan penyerahan bantuan berupa peralatan biopori, peralatan pemrosesan POC, contoh produk POC, bibit tanaman serta bakteri EM4. 


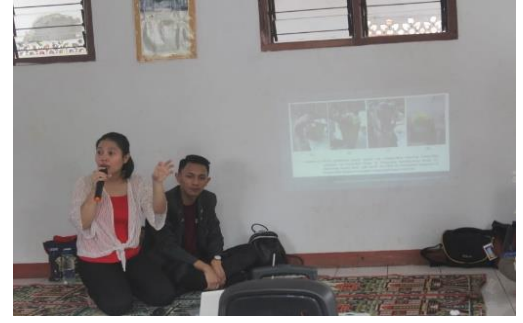

a

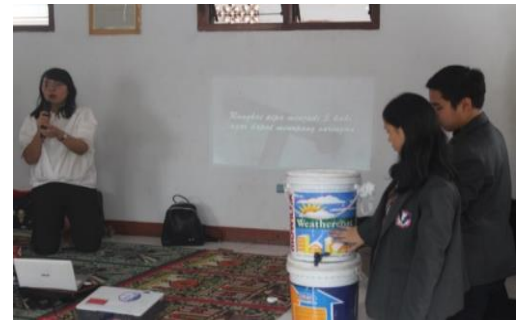

$\mathrm{b}$

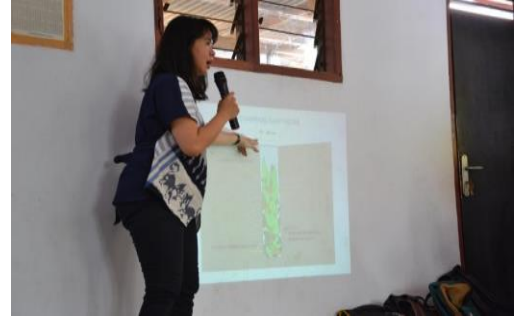

C

Gambar 3 a,b, dan c Kegiatan penyampaian materi pupuk organik cair aerob dan anaerob serta sistem biopori oleh narasumber.

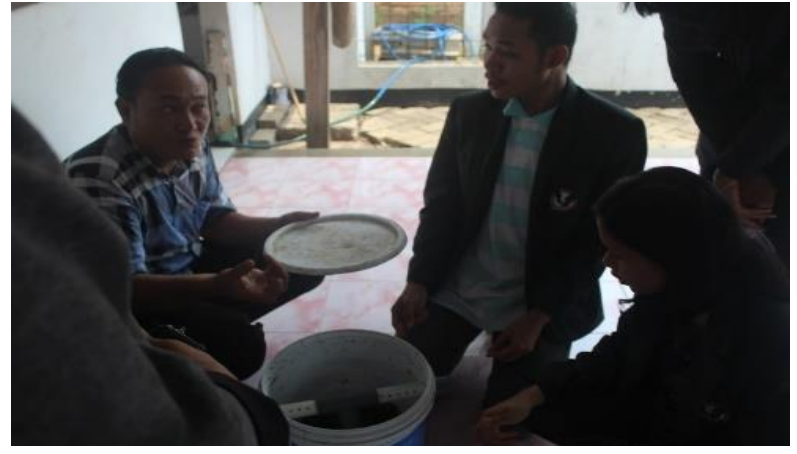

a

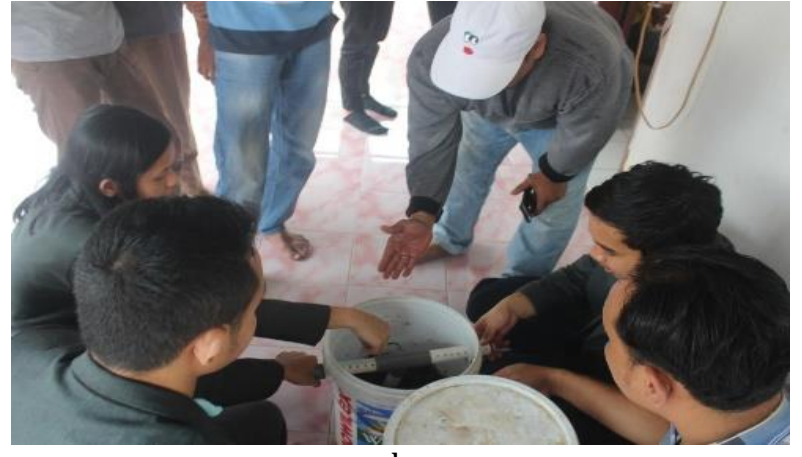

b

Gambar 4 a) Diskusi dengan warga tentang rancangan alat pemrosesan pupuk organik cair dan b) Mahasiswa menunjukan dan menjelaskan alat pemrosesan pupuk organik cair.

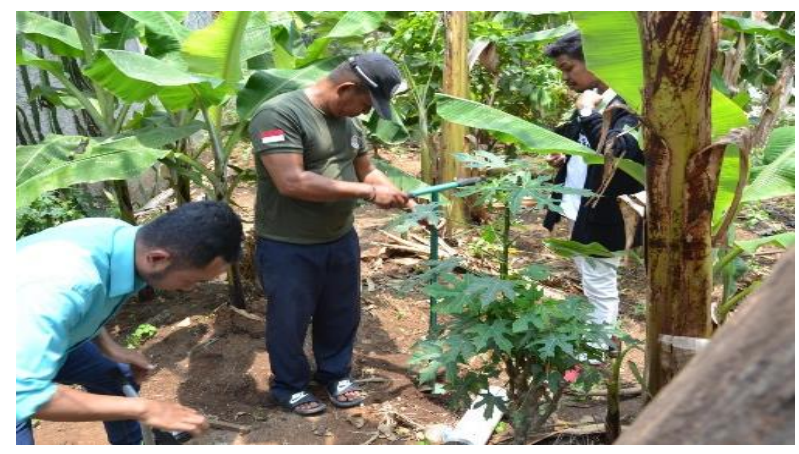

a

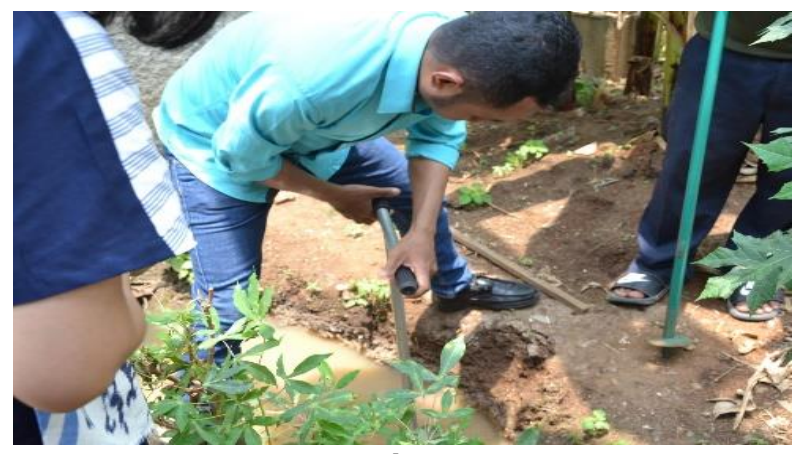

b

Gambar 5 Praktik pembuatan lubang biopori a) Oleh warga dan b) Oleh dosen.

Saat kegiatan ramah tamah, tim membagikan kuesioner sebagai bentuk evaluasi kegiatan. Selain itu, mahasiswa juga melakukan wawancara langsung dan mem-buat video sebagai dokumentasi keseluruhan kegiatan tersebut.

Pengetahuan dan implementasi teknologi pengelolaan sampah yang disampaikan membuat warga yang dulunya mengelola sampah (organik dan non-organik) dengan cara dibakar dapat mengelola sampah dengan cara lain yang lebih menguntungkan dari segi lingkungan, kesehatan, dan ekonomi. Pembuatan POC jika digeluti dengan baik dapat menjadi sumber pendapatan tambahan bagi warga karena dapat dijual hingga Rp 150.000/L. Selain itu, rangkaian kegiatan yang telah dilakukan juga mendorong warga untuk bercocok tanam secara mandiri di sekitar rumah untuk keperluan sehari-hari. Warga mendapat sumbangan bibit tanaman untuk dikembangkan. Berdasarkan hasil monitoring ketua tim PkM dengan ketua RT, warga baru memulai menanam saat bulan Desember karena kemarau panjang yang terjadi di tahun 2019, sehingga menyebabkan warga kesulitan mendapatkan air.

Selama pelaksanaan kegiatan warga Kampung Babakan memberikan respons yang sangat positif berdasarkan jawaban mereka pada kuesioner. Banyak warga yang sangat antusias, hal ini terlihat dari banyaknya pertanyaan yang disampaikan pada tim PkM dan keikutsertaan warga secara aktif dalam workshop pembuatan alat, pemrosesan POC, serta pembuatan lubang 
biopori. Selain itu, berdasarkan wawancara yang dilakukan oleh mahasiswa seputar keberhasilan dan manfaat kegiatan PkM yang telah dilaksanakan, warga merasa mendapat pengetahuan baru yang sangat berharga karena selama ini solusi pengelolaan sampah hanya dengan cara dibakar. Warga mendapatkan opsi tambahan untuk mengelola sampah terutama sampah organik mlalui kegiatan pengabdian ini. Warga juga sangat antusias ketika mengetahui bahwa pengelolaan sampah organik dengan pembuatan POC juga dapat memberikan banyak keuntungan serta dapat dijadikan usaha sampingan jika ditekuni dengan baik. Tambahan pengetahuan tentang keuntungan biopori seperti mengurangi potensi banjir dan luapan kali saat musim hujan juga menjadi nilai tambah dari pelaksaan kegiatan ini.

Evaluasi pelaksanaan PkM dilakukan dengan kuesioner dan video dokumentasi. Hasil kuesioner dijabarkan pada Tabel 1 sedangkan video dokumentasi pelaksanaan kegiatan dapat diakses melewati media youtube dengan alamat berikut

https://www.youtube.com/watch?v=ZSIX_maH NfM\&t=835s. Video yang dibuat berisi pelaksanaan kegiatan penyuluhan, workshop pembuatan peralatan POC, demo pembuatan lubang biopori, serta tanggapan empat orang perwakilan warga terhadap pelaksanaan kegiatan PkM. Keempat tanggapan warga menunjukan respons yang positif yang menunjukkan tujuan pelaksanaan PkM ini berhasil terlaksana dengan baik. Perwakilan warga yang memberi tanggapan juga sangat beraharap ada kegiatan lanjutan yang melibatkan warga dalam jumlah yang lebih banyak. Sejalan dengan keberhasilan Zulaihah et al. 2018 dalam implementasi biopori serta keberhasilan Widiyastuti \& Kartono (2019) dalam implementasi POC dalam usaha peningkatan kesadaran pengelolaan sampah dan kesehatan lingkungan masyarakat, kegiatan pengenalan POC dan sistem biopori pada warga kampung Babakan, Tangerang juga telah meningkatkan kesadaran warga dalam pengelolaan sampah organik dan mendorong masyarakat untuk mempraktekan pengetahuan yang telah diperoleh.

\section{SIMPULAN}

Kegiatan PkM pengenalan pupuk organik cair (POC) dan sistem biopori sebagai solusi pengelolaan sampah di Kampung Babakan, Binong, Kabupaten Tangerang berlangsung dengan baik yang ditunjukkan dengan antusias peserta yang aktif dan baik dalam mengikuti kegiatan. Berdasarkan hasil evaluasi dan wawancara, pelaksanaan PkM ini berhasil meningkatkan kesadaran warga tentang pengelolaan sampah dan kesehatan lingkungan serta mendorong warga untuk mengaplikasikan pengetahuan tentang pembuatan POC dan sistem biopori untuk mengelola sampah organik dilingkungan mereka. Selain itu, pelaksanaan PkM ini juga berhasil mejadi wadah bagi dosen dan mahasiswa yang terlibat untuk membagikan pengetahuan kepada masyarakat, meningkatkan kemampuan berkomunikasi, serta melatih kemampuan berpikir kreatif dalam perancangan alat untuk pengembangan teknologi sederhana seperti alat pemrosesan POC bagi masyarakat.

Pelaksanaan PkM berikutnya dapat dilanjutkan dengan memberikan pelatihan pemanfaatan botol plastik maupun sampah plastik lainnya sebagai wadah penanaman hidroponik serta metode pengelolaan sampah plastik lainnya

Tabel 1 Hasil kuisioner PkM penyuluhan POC dan biopori

\begin{tabular}{lrrr}
\multicolumn{1}{c}{ Pernyataan } & $\begin{array}{c}\text { Setuju } \\
(\%)\end{array}$ & $\begin{array}{c}\text { Tidak } \\
\text { setuju (\%) }\end{array}$ & $\begin{array}{c}\text { Tidak } \\
\text { menjawab (\%) }\end{array}$ \\
\hline Cara pengelolaan sampah selama ini disampaikan kurang efektif & 77 & 23 & 0 \\
Penyuluhan sangat membantu & 100 & 0 & 0 \\
Penyuluhan meningkatkan kesadaran masyarakat & 89 & 0 & 11 \\
Penyuluhan membuka wawasan untuk perduli lingkungan & 100 & 0 & 0 \\
Saya lebih memahami pemilahan dan pengelolaan sampah ramah & 100 & 0 & 0 \\
lingkungan & 100 & 0 & 0 \\
Bahan untuk membuat POC dan biopori mudah didapatkan & 100 & 0 & 0 \\
Saya tergerak menerapkan di rumah & 100 & 0 & 0 \\
Saya bersedia mengajak masyarakat mengelola sampah setelah & & 11 \\
penyuluhan ini & 78 & 11 & 0 \\
Program ini mengganggu rutinitas & 89 & 11 & \\
Penyuluhan serupa perlu diadakan kembali & & & 0 \\
\hline
\end{tabular}


karena di Kampung Babakan masih terlihat sampah plastik. Hal tersebut bertujuan untuk mencapai hasil yang lebih optimal, sehingga warga Kampung Babakan dapat menjadi warga mandiri mengelola sampah secara menyeluruh dan kualitas kesehatan serta lingkungan di kampung ini menjadi yang lebih baik.

\section{UCAPAN TERIMA KASIH}

Terima kasih kepada masyarakat Kampung Babakan, Binong, Kabupaten Tangerang yang bekerja sama dalam pelaksanaan kegiatan PkM ini. Selain itu, ucapan terima kasih juga disampaikan kepada LPPM UPH yang telah memberi dukungan dalam pembiayaan kegiatan Pengabdian kepada Masyarakat ini, yang dinyatakan pada pelaporan nomor PM-031FIP/V/2019.

\section{DAFTAR PUSTAKA}

[BPS] Badan Pusat Statistik. 2016. Kajian Indikator Lintas Sektor; Potret Awal Tujuan Pembangunan Berkelanjutan (Sustainable Development Goals) di Indonesia.

[BPS] Badan Pusat Statistik. 2018. Statistik Lingkungan Hidup Indonesia, Pengelolaan Sampah di Indonesia.

Brata KR, Nelistya A. 2008. Lubang Resapan Biopori. Jakarta (ID): Penebar Swadaya.

Febriana M, Prijono S, Kusumarini N. 2018. Pemanfaatan Pupuk Organik Cair untuk Meningkatkan Serapan Nitrogen serta Pertumbuhan dan Produksi Sawi (Brassica juncea L.) pada Tanah Berpasir. Jurnal Tanah dan Sumberdaya Lahan. 5(2): 1009-1018.

Hadisuwito S. 2007. Membuat Pupuk Kompos Cair. Jakarta (ID): Agomedia Pustaka.

Juliandari M, Nirmala A, Yuniarti E. 2013. Efektivitas Lubang Serapan Biopori Terhadap Laju Resapan (Infiltrasi). Jurnal Teknologi Lingkungan Lahan Basah. 1(1): 1-10. https://doi.org/10.26418/jtllb.v1i1.3441

Marpaung AE. 2017. Pemanfaatan Jenis dan Dosis Pupuk Organik Cair (POC) untuk Meningkatkan Pertumbuhan dan Hasil Sayur Kubis. Jurnal Argoteknosains. 1(2): 117-123.

Marpaung AE, Karo B, Tarigan R. 2014. Pemanfaatan Pupuk Organik Cair dan Teknik
Penanaman dalam Peningkatan Pertumbuhan dan Hasil Kentang. Jurnal Hortikultura. 24(1): 49-55.

Miller GT, Spoolman SE. 2009. Living in The Environment: Concepts, Connections, and Solutions. $16^{\text {th }}$ Editions. USA: Brooks/Cole, Cengange Learning.

Nur T, Noor AR, Elma M. 2016. Pembuatan Pupuk Organik Cair dari Sampah Organik Rumah Tangga dengan Penambahan Bioaktivator EM4 (Effective Microorganisms). Konversi. 5(2): 44-51. https://doi.org/10.20527/ k.v5i2.4766

Purwaningrum P. 2016. Upaya Mengurangi Timbunan sampah Plastik di Lingkungan. Jurnal Teknik Lingkungan Trisakti. 8(2): 141$147 . \quad$ https://doi.org/10.25105/ urbanenvirotech.v8i2.1421

Puspadewi S, Sutari W, Kusmiati. 2016. Pengaruh Konsentrasi Pupuk Organik Cair (POC) dan Dosis Pupuk N, P, K terhadap Pertumbuhan dan Hasil Tanaman Jagung Manis (Zea mays L. var Rugosa Bonaf) kultivar Talenta. Jurnal Kultivasi. 15(3): 208-216. https://doi.org/ 10.24198/kltv.v15i3.11764

Sari AM. 2018. Estimasi Emisi Metana $\left(\mathrm{CH}_{4}\right)$ dari TPA Tamangapa. [Skripsi]. Makasar (ID): Universitas Hasanuddin.

Sentana S. 2010. Pupuk Organik, Peluang dan Kendalanya. In: Prosiding Seminar Nasional Teknik Kimia Kejuangan. UPN Veteran Yogyakarta. Yogyakarta (ID): 26 Januari 2010.

Widiyastuti T, Kartono. 2019. Pengelolaan Sampah Rumah Tangga untuk Mendukung "Program Kotaku" Pada Kelompok PKK Perumahan Griya Satria Bancarkembar Kecamatan Purwokerto Utara Kabupaten Banyumas. In: Prosiding Seminar Nasional 2019. Universitas Jenderal Soedirman. Purwekerto (ID), 15 November 2019.

Zaini H. 2015. Pupuk Organik Cair dan Pupuk Organik Padat bagi Budi daya Pisang Barangan. Jurnal Handayani. 4(1): 126-135.

Zulaihah L, Siregar AH, Marasabessy A. 2018. Pengelolaan Sampah Organik Berbasis Biopori di Kelurahan Bojong Kulur, Kecamatan Gunung Putri, Kabupaten Bogor. In: Prosiding Seminar Nasional Penelitian dan Pengabdian Kepada Masyarakat. Universitas Bangka Belitung, Pangkalpinag (ID). 2 Oktober 2018. 